\title{
Legal Protection for Nurses in Non Civil Servants in Health Centers in Langgudu Sub-District Bima Regency After the Enactment of Law Number 38 the Year 2014 concerning Nursing
}

\author{
Perlindungan Hukum Bagi Tenaga Perawat Non Pegawai Negeri Sipil di Puskesmas Pada \\ Kecamatan Langgudu Kabupaten Bima Setelah Berlakunya Undang-Undang Nomor 38 \\ Tahun 2014 Tentang Keperawatan
}

Al Muhajirin, Tjahjono Kuntjoro, Yovita Indrayati email: muhajirinbima311@gmail.com

Health Law Master Program, Soegijapranata Catholic University of Semarang

\begin{abstract}
Local Government Clinic in Langgudu Subdistrict, Bima Regency, is one of the Government institutions that employ health and non-health workers. One of the health workers themselves is nurses. Nurses who practiced at the clinic have recruited both nurses who have status of civil servants, impermanent officers, and voluntary nurses. The voluntary nurses who were rectuired and appointed by the head of the clinic. On the other hand, the recruitment in the local government should comply the legislation of the state civil apparatus. As the recruitment is not in accordance to the legislation of the state civil apparatus, it will has impact on the legal protection for the nurses in local goverment clinic.

This research was done at clinic in Langgudu subdistrict of Bima Regency usingsociology juridical research method. The specification of the research was descriptive analytic using primary and secondary data. Data collection techniques used in the research was face to face interview, question draft distribution and interview by phone. The Information or resource of this research was the head of the health official, heads of clinics in Langgudu subdistric and the chairman of Indonesian National Nurses Organization of Bima regency. Then, The respondents were the nurses who work at the clinic in Langgudu Subdistrict, either nurses who have status of civil servant, local honorary workers or the voluntary nurses.
\end{abstract}

The research result found that the regulation of employee appointment to work in government institution was set in regent's regulation number $15 \mathrm{~A}$ about appointment guideline, placement, Dismissal, and honorary workers discipline of local goverment. In the regulation, the person who has authority in appointing the employees is the regent as the builder of the officers. In impelementing of the regulation the head of the Clinic appointsnurse workers by himself to employ at the clinic. Thus, such things have already brokenauthority as leader of institution in the sphere of local government as it is not in accordance with the rules of the Regent of Bima. Therefore, the such appointementis an obstacle in giving protection for voluntary Nurses because the process of appointment is not appropriate and breakig authority. As a head of clinics is not given authority and should not recruit or appoint the workers to employ at government institutions. The appointment of the workers shows that understanding of heads of clinics about management of the worker appointment at the clinics still lack, in addition to the absence of legislation regulations managing the volunteers so that it is an obstacle in providing legal protection for voluntary nurses who work in a clinic.

Keywords: Legal Protection, Impermanent Nurses, Local Government Clinic 


\section{PENDAHULUAN}

Pengembangan dan pemberdayaan tenaga tenaga kesehatan dapat dikatakan sebagai unsur kesejahteraan umum karena tugas tenaga kesehatan yaitu memberikan pelayanan kesehatan kepada masyarakat khususnya pada wilayah kerja Puskesmas sebagai pusat pelayanan kesehatan tingkat pertama.Seorang yang bekerja pada instansi pemerintah tentunya mengharapkan imbalan jasa yang akan di pergunakan dalam mencukupi kebutuhan hidupnya atau dengan kata lain seorang pekerja yang bekerja pada instansi pemerintah salah satu tujuanya adalah untuk melangsungkan kehidupannya.Hubungan antara pemerintah dan tenaga kesehatan dibutuhkan suatu aturan yang dapat mengatur hak dan kewajiban kedua belah pihak agar tenaga kesehatan dan pemerintah sebagai pemberi kerja mendapatkan suatu perlindungan atas hak-haknya dan kewajiban-kewajiban yang wajib dipenuhi.

Tenaga kesehatan yang bekerja pada instansi milik pemerintah merupakan tenaga yang mengabdikan diri dalam memberikan pelayanan kesehatan kepada masyarakat, untuk itu tenaga kesehatan berhak mendapatkan penghidupan yang layak atas pekerjaan. Hal ini diatur dalam Pasal 27 ayat (2) Undang-Undang Dasar Republik Indonesia Tahun 1945 yang menerangkan bahwa: "Tiap-tiap warga negara berhak atas pekerjaan dan penghidupan yang layak bagi kemanusiaan”. Selain pemenuhan hak atas pekerjaan, tenaga kesehatan juga berhak mendapatkan perlakuan khusus guna mencapai persamaan dan keadilan, hal ini sebagaiman yang telah diatur dalam pasal $28 \mathrm{H}$ ayat (2) yang menerangkan bahwa, "Setiap orang berhak mendapat kemudahan dan perlakuan khusus untuk memperoleh kesempatan dan manfaat yang sama guna mencapai persamaan dan keadilan". Sebagai kelanjutan dari pasal tersebut munculah Undang-Undang Nomor 36 Tahun 2014 Tentang Tenaga kesehatan yang mencakup perlindungan hukum, hak dan tanggung jawab pihak-pihak yang terkait dari berbagai aspek tenaga kesehatan.

Tenaga kesehatan dalam menjalankan tugas adalah memberikan pelayanan kesehatan kepada masyarakat sesuai dengan profesinya masing-masing. Salah satunya adalah tenaga Perawat yang dalam menjalankan profesinya untuk memberikan pelayanan keperawatan pada masyarakat. Adapun pelayanan Keperawatan adalah suatu bentuk pelayanan profesional yang merupakan bagian integral dari pelayanan kesehatan yang didasarkan pada ilmu dan kiat Keperawatan ditujukan kepada individu, keluarga, kelompok, atau masyarakat, baik sehat maupun sakit.

Namun profesi Perawat ini sangat di sayangkan karena tenaga Perawat dalam mengabdikan dirinya pada instansi pemerintah masih banyak yang belum mendapatkan haknya sebagai pegawai. Hal ini dapat di lihat pada Puskesmas bahwa tenaga Perawat masih banyak yang statusnya sebagai tenaga Pegawai Non PNS khususnya di Kabupaten Bima Provinsi Nusa Tenggara Barat. Adapun jumlah Tenaga Perawat Non PNS di Kabupaten Bima pada tahun 2016 sebanyak 597 orang yang terdiri dari tenaga Perawat Pegawai Tidak Tetap yang selanjutnya di sebut PTT Daerah sebanyak 74 orang, kemudian tenaga Perawat Honorer Daerah sebanyak 17 orang dan tenaga Perawat Sukarela sebanyak 506 Orang.

Tenaga Perawat yang Non PNS di Kabupaten Bima bayak yang berfikir Negatif terhadap profesi Perawat, karena bekerja sebagai tenaga Perawat pada instansi pemerintah tidak menjamin hidup makmur. Adanya pandangan tersebut di karenakan adanya kurang pemenuhan kebutuhan hak atas kewajiban yang tidak sesuai dengan beban kerja. 
Permasalahan yang ada di dunia kesehatan khususnya Perawat saat ini dapat kita lihat bahwa angka dari jumlah pengangguran yang semakin meningkat, yang kenyataannya bukan hanya dipengaruhi oleh keterbatasan lapangan kerja akan tetapi karena adanya perbedaan yang cukup besar antara hasil kerja dengan kebutuhan kerja. Sehingga tingkat kesejahteraan Perawat Non PNS khususnya yang Sukarela masih memprihatinkan seperti salah satunya di Kabupaten Bima, karena upah atau gaji yang di terima oleh tenaga Perawat Non PNS yang ada di Kabupaten Bima khususnya tenaga Perawat Sukarela yang mengabdikan diri pada Puskesmas sangatlah sedikit dan bahkan tidak mendapatkan upah atau gaji dari pemerintah daerah.

Tujuan keluarnya Undang-Undang Keperawatan sebenarnya untuk memberikan perlindungan dan kepastian hukum bagi tenaga perawat, meningkatkan mutu Perawat dan mutu Pelayanan Keperawatan serta meningkatkan derajat kesehatan masyarakat.Peningkatan mutu Perawat tidak terlepas dari pengangkatan dan penempatan tenaga Perawat pada satuan instansi pelayanan kesehatan Puskesmas yang diselenggarakan oleh pemerintah atau pimpinan instansi berdasarkarkan kesepakatan kerja yang artinya antara pemerintah atau pimpinan sebagai pemberi kerja dengan tenaga Perawat sebagai penerima kerja yang saling membutuhkan satu sama lain. Adapun saling mebutuhkan yang dimaksud adalah pemerintah mempekerjakan tenaga Perawat untuk memberikan pelayanan keperawatan kepada masyarakat kemudian tenaga Perawat di upayakan untuk mendapatkan imbalan atas pekerjaanya sebagai tenaga Keperawatan yang bekerja pada Puskesmas sebagai instansi milik pemerintah tersebut.

Pemerintah Untuk mengangkat Perawat yang profesional pada bidangnya memang membutuhkan dana yang tidak sedikit, sehubungan dengan sistem penggajian yang ada di Puskesmas sebagai Penyelenggara tenaga Kesehatan khususnya tenaga Perawat sukarela yang tidak tentu adanya. Maka jalan yang paling mudah ditempuh oleh pemerintah adalah dengan mengupayakan melakukan kontrak dan membuat perjanjian kerja waktu tertentu dengan tenaga Perawat yang dibutuhkan agar tenaga Perawat yang bekerja pada Puskesmas agar mendapatkan haknya sebagai pegawai yang bekerja pada instansi pemerintah. Sewalaupun hal ini juga merupakan suatu kesulitan tersendiri dalam pelaksanaanya, akan tetapi pemerintah harus berupaya demi memenuhi hak Perawat sebagai tenaga kerja pada instansi pemerintah yang dalam hal ini adalah Puskesmas.

\section{RUMUSAN MASALAH}

Dengan adanya tenaga perawat yang bekerja di Puskesmas pada kecamatan langgudu yang di angkat oleh Kepala uskesmas tanpa di berikan haknya atas pekerjaan yang di bebankan oleh pemerintah dalam memberikan pelayanan kesehatan kepada masyarakat mengakibatkan munculnya permasalahan yang di hadapi oleh pemerintah dalam memberikan perlindungan hukum bagi tenaga perawat yang di angkat oleh Kepala Puskesmas pada Kecamatan Langgudu. Adapun rumusan masalah yang timbul adalah bagaimanakah pengaturan, dan bagaimana pelakasanaan serta bagaimana hambatan perlindungan hukum bagi perawat non pegawai negeri sipil di Puskesmas pada Kecamatan Langgudu, Kabupaten Bima setelah berlakunya Undang-Undang Nomor 38 Tahun 2014 Tentang Keperawatan. 


\section{METODE PENELITIAN}

Penelitian ini di lakukan pada Puskesmas di Kecamatan Langgudu kabupaten Bima dengan menggunakan metode pendekatan yurdis sosiologis. Kemudian spesifikasi data pada pnelitian ini adalah deskriptif analitik dengan menggunakan desain penelitian Kualitatif.Data yang di gunakan dalam penelitian ini ada dua yaitu data Primer dan dara sekunder. Adapun data sekunder ini terdiri dari tiga bahan hukum yaitu bahan hukum primer, bahan hukum sekunder dan bahan hukum tersier. Adapun Lokasi pengumpulan data yang di lakukan oleh peneliti adalah dilakukan di Puskesmas pada Kecamatan Langgudu Kabupaten Bima Provinsi Nusa Tenggara Barat (NTB) dengan menggunakan metode kualitatif.

Metode penelitian kualitatif adalah metode penelitian yang berlandaskan pada filsafat postpositivisme, di gunakan untuk meneliti kondisi objek yang alamiah, (sebagai lawanya adalah ekperimen) di mana penelitian adalah sebagai instumen kunci, tehnik pengumpulan data di lakukan secara triangulasi (gabungan) analisis data bersifat individu/kualitatif dan hasil penelitian kualitatif lebih menekankan makna dari pada generalisasi. ${ }^{1}$ Pengumpulan data dapat di lakukan secara kualitatif yaitu wawancara mendalam yang di lengkapi dengan data kualitatif menggunakan kuesioner penelitian. Informasi atau narasumber dalam penelitian ini adalah Kepala Dinas Kesehatan, Kepala Puskesmas di Kecamatan Langgudu dan ketua PPNI Kabupaten Bima. Adapun sebagai kosionernya adalah Perawat yang berada di Puskesmas Langgudu barat dan Puskesmas Langgudu Timur.

1. Wawancara dengan pejabat Dinas Kesehatan Kabupaten Bimadengan tujuan untuk mengetahui langkah dan hambatan Dinas Kesehatan dalam melakukan perekrutan tenaga perawat untuk di pekerjakan pada Puskesmas kecamatan Langgudu.

2. Wawancara dengan kepala Puskesmas untuk mengetahui sejauh mana peran yang di lakukan Puskesmas terkait denganperekrutan dan penempatanserta sistim pemberian gaji Perawat Non PNS khususnya tenaga sukarelayang bekerja di Puskesmas pada Kecamatan Langgudu sebagai instansi pemerintah. Selain itu untuk mengetahui ada tidak dasar hukum Kepala Puskesmas menempatkan dan menerima atau merekrut tenaga kesehatan khususnya tenaga Perawat dalam memberikan Pelayanan Keperawatan.

3. Wawancara terhadap Perawatbertujuan untuk mengetahui tentang syarat, langkah dan proses perekrutan yang dilakukan oleh Kepala Puskesmas terhadap tenaga kesehatan khususnya Perawat. Selain itu juga untuk mengetahui, apakah tenaga Perawat yang di angkat oleh Kepala Puskesmas untuk di pekerjakan pada Puskesmas mendapatkan gaji atau tidak.

Analisa data merupakan pekerjaan untuk menemukan tema-tema dan merumuskan hipotesa-hipotesa, meskipun sebenarnya tidak ada formula yang pasti untuk dapat di gunakan merumuskan hipotesa. ${ }^{2}$ Dengan demikian data yang telah di dapatkan baik itu dari data Primer ataupu sekunder terlebih dahulu akan di olah kemudian setelah itu akan di analisa kemudian disajikan dengan cara deskripsi.

Tujuan Pengumpulan data dengan cara deskripsi ini yaitu untuk menjelaskan, menguraikan dan menggambarkan sesuai dengan suatu permasalahan yang ada kaitanya dengan penelitian yang akan diteliti oleh peneliti. Setelah di deskripsikan baru ditarik suatu

\footnotetext{
'Sugiono : 2015, Metode Penelitian akuantitatif, kualitatif, R\&D. Bandung : Alfabeta. Hal, 9
}

${ }^{2}$ Burhan Ashshofa, 2013, Metode Penelitian Hukum, Jakarta : Rineka Cipta Hal, 66 
kesimpulan yang berdasarkan dengan apa yang ada dari hasil analisis yang telah diteliti. Sehingga dengan begitu akan dapat memberikan suatu gambaran yang terkait dengan perekrutan atau penerimaan dan penempatan tenaga Perawat Non PNS dalam memberikan pelayanan keperawatan serta proses pemberian upah atau gaji oleh pemerintah dan Kepala dalam pemenuhan hak-hak Perawat sebagai pegawai yang bekerja pada wilayah kerja Puskesmas. Hal tersebut sudah sesuai dengan ketentuan Peraturan Perundang-Undangan yang berlaku atau tidak.

\section{PEMBAHASAN}

1. Pengaturan perlindungan hukum bagi Perawat Non PNS di Puskesmas pada Kecamatan Langgudu, Kabupaten Bima setelah berlakunya Undang-Undang Nomor 38 Tahun 2014 tentang Keperawatan.

Peraturan Perundang-Undangan merupakan produk hukum secara tertulis yang dibentuk dan dirancang kemudian ditetapkan oleh pejabat negara yang berwewenang, isi dari setiap peraturan Perundang-Undangan harus sesuai dengan norma. Pengaturan perlindungan hukum terhadap tenaga atau pegawai yang bekerja pada instansi pemerintah merupakan kewenagan dari pemerintah baik itu pemerintah Pusat maupun pemerintah Daerah Propinsi dan pemerintah Daerah Kabupaten/Kota.

\section{a. Pengaturan perlindungan}

Adapun yang berhak mengangkat tenaga untuk di pekerjakan pada Puskesmas sebagai instansi Pemerintah adalah Bupati sebagai Pejabat Pembina Kepegawaian sebagaimana yang di atur dalam Pasal 1 angka 6 Peraturan Bupati Bima Tentang Pedoman Pengangkatan, Penempatan, Pemberhentian dan Disiplin Honorer Daerah Lingkup Pemerintah Kabupaten Bima yang menerangkan bahwa : "Pejabat yang Berwenang adalah Pejabat Pembina Kepegawaian yang mempunyai kewenangan mengangkat, memindahkan dan memberhentikan Tenaga Honorer Daerah".

Pengangkatan tenaga untuk di pekerjakan pada instansi pemerintah oleh Bupati sebagai Pejabat Pembina Kepegawaian sebagaimana yang di atur dalam Peraturan Bupati Biama tersebut juga di atur dalam Pasal 1 angka 2 Undang-Undang ASN yang menerangkan bahwa : "Dalam Undang-Undang ini yang dimaksud dengan Pegawai Aparatur Sipil Negara yang selanjutnya disebut Pegawai ASN adalah pegawai negeri sipil dan pegawai pemerintah dengan perjanjian kerja yang diangkat oleh pejabat pembina kepegawaian dan diserahi tugas dalam suatu jabatan pemerintahan atau diserahi tugas negara lainnya dan digaji berdasarkan peraturan perundangundangan".

Dengan adanya pengangkatan tenaga oleh Bupati maka dapat memberikan perlindungan dan kepastian hukum bagi setiap tenaga yang di angkat untuk mengabdikan dirinya pada pada instansi pemerintah. Perlindungan yang di maksud adalah perlindungan atas haknya sebagai pegawai sedangkan kepastian hukum yang di makasud adalah kepastian hukum sebagai pegawai yang bekerja pada instansi Pemerintah. Adapun hak pegawai yang di maksud sebagaimana yang diatur dalam Pasal 23 Peraturan Bupati Bima Nomor 15 ${ }^{\mathrm{A}}$ Tahun 2014 TentangPedoman Pengangkatan, Penempatan, Pemberhentian Dan Disiplin Tenaga Honorer Daerah Lingkup Pemerintah Kabupaten Bima yang menerangkan bahwa : "Dalam melaksanakan tugasnya Tenaga Honorer Daerah berhak memperoleh Gaji, cuti, 
perlindungan, dan pengembangan kompetensi". Hak tenaga sebagaimana dalam Peraturan Bupati Bima tersebut di atur pula dalam Pasal 22 Undang-Undang Nomor 5 Tahun 2014 Tentang Aparatur Sipil Negara yang menerangkan bahwa : "PPPK berhak memperoleh gaji dan tunjangan, cuti, perlindungan dan pengembangan kompetensi".

Tenaga Perawat yang bekerja pada Puskesmas dengan adanya Peraturan Bupati Bima dan Undang-Undang ASN tersebut maka dapat di jadikan acuan dalam memenuhi hak-hak pegawai yang bekerja pada instansi pemerintah. Sehingga dengan demikian dapat memberikan perlindungan hukum bagi tenaga Perawat pada Puskesmas karena tujuan di bentuknya Undang-Undang Keperawatan untuk memberikan perlindungan bagi tenaga Perawat hal tersebut sebagaimana yang di atur dalam Pasal 2 huruf $f$ Undang-Undang Keperawatan yang menyebutkan bahwa : “Praktik Keperawatan berasaskan Perlindungan". Perlindungan bagi tenaga Perawat yang merupakan bagian dari Tenaga Kesehatan di atur pula dalam Pasal 2 huruf i Undang-Undang Tenaga Kesehatan yang menyebutkan bahwa : "Undang-Undang ini berasaskan Perlindungan".

Perlindungan pekerja dapat dilakukan, baik dengan jalan memberikan tuntutan, maupun dengan jalan meningkatkan pengakuan hak-hak asasi manusia, perlindungan fisik dan teknis serta sosial dan ekonomis melalui norma yang berlaku dalam lingkungan kerja itu. ${ }^{3}$ Pengaturan perlindungan bagi tenaga Perawat yang bekerja pada instansi pemerintah di atur dalam Pasal 23 huruf c Peraturan Bupati Bima Tentang Pedoman Pengangkatan, Penempatan, Pemberhentian Dan Disiplin Tenaga Honorer Daerah Lingkup Pemerintah Kabupaten Bima yang menerangkan bahwa : "Dalam melaksanakan tugasnya Tenaga Honorer Daerah berhak memperoleh Perlindungan". Perlindungan tersebut juga di atur dalam Pasal 22 huruf c yang menerangkan bahwa, "PPPK berhak memperoleh perlindungan".

Berkaitan dengan hal tersebut di atas, Imam Soepomo membagi perlindungan pekerja ini menjadi 3 (tiga) macam yaitu $:^{4}$

1. Perlindungan ekonomis, yaitu suatu jenis perlindungan yang berkaitan dengan usaha-usaha untuk memberikan kepada pekerja suatu penghasilan yang cukup memenuhi keperluan sehari-harinya baginya beserta keluargannya, termasuk dalam hal pekerja tersebut tidak mampu bekerja karena sesuatu di luar kehendaknya. Perlindungan ini disebut jaminan sosial.

2. Perlindungan sosial, yaitu suatu perlindungan yang berkaitan dengan usaha kemasyarakatan, yang tujuannya memungkinkan pekerja itu mengenyam dan mengembangkan prikehidupan sebagai manusia pada umumnya, dan sebagai anggota masyarakat dan anggota keluarga atau yang biasa disebut kesehatan kerja.

3. Perlindungan Teknis, yaitu suatu jenis perlindungan yang berkaitan dengan usaha-usaha untuk menjaga pekerja dari bahaya kecelakaan yang dapat

\footnotetext{
${ }^{3}$ Greta Satya Yudhana, 2015, Jurnal Pelaksanaan Perlindungan Hukum Bagi Pekerja Honorer Kebersihan Kota Di Pemda Yogyakarta, Hal, 6. Yang Di Akses Dari : http://e-journal.uajy.ac.id/8019/1/JURNAL.pdf , Pada Tanggal 15 pebruari 2018 Jam 19:17 WIB

4 Wahab,S.H.,Lalu Husni,S.H.,M.H.Hum.,Zaenal Asyhadie,S.H.,M.Hum, Dasar-Dasar Hukum Perburuhan, 2010, Rajawali Pers, Jakarta. hlm.96-97
} 
ditimbulkan oleh pesawat-pesawat atau alat kerja lainnya atau oleh bahan yang diolah atau dikerjakan perusahaan. Didalam pembicaraan selanjutnya, perlindungan jenis ini disebut dengan keselamatan kerja.

Adanya hak untuk mendapatkan perlindungan hukum tersebut merupakan kewajiban pemerintah yang menjadi hak tenaga Perawat sebagai pegawai yang bekerja pada instansi pemerintah, salah satunya tenaga Perawat yang bekerja pada Puskesmas. Menurut Ridwan, salah satu pilar negara hukum adalah asas legalitas, yang berarti bahwa setiap tindakan hukum pemerintah baik yang di lakukan pemerintah pusat maupun pemerintah daerah harus berdasarkan pada Peraturan Perundang-Undangan. ${ }^{5}$

Dengan berdasarkan pada fries ermensen, Pemerintah Daerah dapat mengeluarkan berbagai peraturan kebijakan (beleidsregel) baik dalam bentuk peraturan (voorshriften), pengumuman-pengumuman (bekenmakingen), pedoman-pedoman (circulaires), instruksi-instruksi (aanschrjvinge), dan sebaginya. Hal pertama, belum ada Perda yang mengatur suatu urusan pemerintah tertentu, sementara hal itu menuntut Pemerintah Daerah untuk mengatur dan mengurusnya. Kedua, sudah ada perda yang mengatur suatu urusan pemerintah tertentu, namun redaksinya samaratau ambigu. Dalam hal ini, Pemerintah daerah di beri ruang kebebasan mempertimbangkan (beordelingsruimte) baik yang subjektif maupun yang objektif (subjective \& objective beordelingsruimte). ${ }^{6}$ Sehubung dengan hal tersebut dengan di keluarkanya surat edaran merupakan kebijan pemerintah untuk seluruh OPD agar tidak melakukan pengangkatan tenaga untuk di pekerjakan pada instansi milik pemerintah.

Pemerintah dalam merencanakan pengangkatan tenaga untuk di pekerjakan pada instansi pemerintah tentunyan sudah menyiapkan anggaran yang akan di keluarkan untuk membiayai atau menggaji tenaga yang akan di angkat, karena gaji merupakan hak tenaga sebagai pegawai. Adapun hak tenaga Perawat yang berkerja pada instansi pemerintah di Kabupaten Bima sebagaiman yang di atur dalam Pasal 23 huruf a Peraturan Bupati Bima Nomor Tentang Pedoman Pengangkatan, Penempatan, Pemberhentian Dan Disiplin Tenaga Honorer Daerah Lingkup Pemerintah Kabupaten Bima yang menerangkan bahwa, "Dalam melaksanakan tugasnya Tenaga Honorer Daerah berhak memperoleh gaji”. Selain itu juga di atur dalam Pasal 22 huruf a Undang-Undang Aparatur Sipil Negara yang menerangkan bahwa, "PPPK berhak memperoleh gaji dan tunjangan".

Tenaga Perawat Non PNS yang bekerja pada instansi pemerintah selama menjalankan tugas berhak untuk mendapatkan imbalan atas pekerjaan yang di bebankan oleh pemerintah. Karena hak untuk mendapatkan upah atau gaji bagi pegawai di atur dalam Peraturan Perundang-Undangan sebagaimana yang telah atur dalam Peraturan Bupati Bima dan Undang-Undang ASN tersebut di atas.

Pengaturan tentang hak Perawat untuk mendapatkan upah atau gaji itu sendiri sebagaimana di atur Pasal 36 huruf c Undang-Undang Keperawatan yang menerangkan bahwa: "menerima imbalan jasa atas Pelayanan Keperawatan yang telah diberikan". Selain di atur dalam Undang-Undang Keperawatan terkait dengan

\footnotetext{
${ }^{5}$ Ridwan, 2009, HukumAdministrasi Di Daerah, Yogyakarta : FH UII Pers, Hal 98

${ }^{6}$ Ibid,Hal. 99-100
} 
hak untuk mendapatkan imbalan jasa di atur pula dalam Pasal 57 huruf c UndangUndang Tenaga Kesehatan yang menerangkan bahwa: "Tenaga Kesehatan dalam menjalankan praktik berhak menerima imbalan jasa".

Upah atau gaji merupakan hak tenaga Perawat Non PNS yang bekerja pada Puskesmas sebagai instansi pemerintah. Adapun hak atas upah atau gaji tersebut sebagaimana yang di atur dalam Pasal 38 ayat (4) Undang-Undang HAM yang menerangkan bahwa : "Setiap orang, baik pria maupun wanita dalam melakukan pekerjaan yang sepadan dengan martabat kemanusiaannya berhak atas upah yang adil sesuai prestasinya dan dapat menjamin kelangsungan kehidupan keluarganya".

Hak untuk mendapatkan imbalan jasa sebagaimana yang atur dalam Undang-Undang Keperawatan dan Undang-Undang Tenaga Kesehatan serta Undang-Undang HAM di atas merupakan hak yang harus di penuhi oleh pemerintah sebagai pemberi kerja. Karena adanya Peraturan Perundang-Undangan merupakan prodak hukum yang di jadikan acuan untuk memberikan hak tenaga atau pegawai yang bekerja pada instansi pemerintah. Adapun hak lain tenaga Perawat Non PNS yang bekerja pada instansi pemerintah adalah hak untuk mendapatkan cuti sebagaimana yang diatur dalam Pasal 23 huruf b Peraturan Bupati Bima Tentang Pedoman Pengangkatan, Penempatan, Pemberhentian Dan Disiplin Tenaga Honorer Daerah Lingkup Pemerintah Kabupaten Bima yang menerangkan bahwa, "Dalam melaksanakan tugasnya Tenaga Honorer Daerah berhak memperoleh cuti". Hak untuk mendapatkan cuti Selain di atur dalam Peraturan Bupati Bima di atur juga dalam Undang-Undang ASN. Adapun pengaturan tentang hak cuti di atur dalam Pasal 22 Huruf b Undang-Undang ASN yang menerangkan bahwa : "PPPK berhak memperoleh cuti".

Tenaga Perawat yang mengabdikan dirinya pada instansi pemerintah sebagaimana yang di atur dalam Peraturan Bupati Bima dan Undang-Undang ASN tersebut di atas memiliki hak untuk mendapatkan cuti. Untuk itu dengan adanya peraturan tersebut dapat di jadikan acuan bagi pemerintah untuk memberikan hak cuti bagi tenaga Perawat yang bekerja pada instansi pemerintah, baik yang Honorer Daerah dan PTT Daerah serta Sukarela.

Tenaga Perawat sebagai pegawai yang bekerja pada instansi pemerintah berhak mendapatkan kepastian hukum bagi setiap pegawai yang bekerja pada instansi pemerintah. Kepastian hukum bagi pegawai yang bekerja pada instansi pemerintah Kabupaten Bima di atur dalam Pasal 2 ayat (1) Peraturan Bupati Bima Tentang Pedoman Pengangkatan, Penempatan, Pemberhentian Dan Disiplin Tenaga Honorer Daerah Lingkup Pemerintah Kabupaten Bima yang menerangkan bahwa : "Peraturan ini dibuat dengan maksud untuk memberikan kepastian hukum dalam Pengangkatan, Penempatan, Pemberhentian dan Disiplin Tenaga Honorer Daerah lingkup Pemerintah Kabupaten Bima". Kepastian hukum bagi tenaga atau pegawai yang bekerja pada instansi pemerintah sebagaimana yang di atur pula dalam Pasal 2 Huruf a Undang-Undang ASN yang menerangkan bahwa : "Penyelenggaraan kebijakan dan Manajemen ASN berdasarkan pada asas kepastian hukum". Yang dimaksud dengan asas kepastian hukum adalah dalam setiap penyelenggaraan kebijakan dan Manajemen ASN, mengutamakan landasan peraturan perundangundangan, kepatutan, dan keadilan. 
Apabila setiap pengangkatan tenaga yang di lakukan oleh pemerintah mengacu pada pada Peraturan Bupati dan Undang-Undang ASN tersebut di atas maka setiap pengangkatan tenaga untuk di pekerjakan pada instansi pemerintah harus memberikan kepastian hukum bagi setiap tenaga atau pegawai yang di pekerjakan pada instansi pemerintah. Karena tujuan dari pengangkatan tenaga adalah untuk memberikan kepastian hukum bagi setiap tenaga yang di rekrut. Kepastian hukum yang di maksud adalah kepastian statusnya sebagai pegawai yang bekerja pada instansi pemerintah.

Kepastian hukum bagi tenaga Perawat di atur dalam Pasal 3 huruf c Undang-Undang Keperawatan yang menerangkan bahwa : "pengaturan keperawatan bertujuan untuk memberikan pelindungan dan kepastian hukum kepada Perawat dan Klien". Kepastian hukum bagi tenaga Perawat yang merupakan bagian dari tenaga kesehatan tersebut di atur dalam Pasal 3 huf e Undang-Undang Tenaga Kesehatan yang menerangkan bahwa : "Undang-Undang ini bertujuan untuk memberikan kepastian hukum kepada masyarakat dan Tenaga Kesehatan".

Kepastian hukum bagi tenaga Perawat yang bekerja pada instansi pemerintah sangat perlu dalam menjalankan tugas karena tujuan dari pembentukan Undang-Undang Keperawatan dan Undang-Undang Tenaga Kesehatan yaitu memberikan perlindungan dan kepastian hukum bagi setiap tenaga kesehatan yang salah satunya adalah tenaga Perawat. Dengan adanya Peraturan Perundang-Undangan tersebut maka dapat di jadikan acuan oleh pemerintah daerah untuk memberikan perlindungan dan kepastian hukum bagi setiap tenaga Perawat yang bekerja pada instansi pemerintah.

Kepastian hukum yang di maksud dalam Undang-Undang Keperawatan dan UndangUndang Tenaga Kesehatan adalah setiap tenaga kesehatan atau tenaga Perawat yang telah menyelesaikan pendidikan maka perlu mendapatkan kepastian hukum yaitu kepastian untuk mendapatkan gelar Perawat sehingga setiap tenaga Perawat yang bekerja pada instansi pemerintah mendapatkan kepastian hukum sebagai pegawai yang bekerja pada instansi pemerintah. Karena tenaga Perawat mempunyai hak atas pekerjaan yang layak sebagaimana yang di atur dalam Pasal 38 ayat (1) Undang-Undang HAM yang menerangkan bahwa : "Setiap warga negara, sesuai dengan bakat, kecakapan, dan kemampuan, berhak atas pekerjaan yang layak". Hak atas pekerjaan yang layak sebagaimana yang di maksud dalam pasal tersebut tidak terlepas dari pengangkatan tenaga untuk di pekerjakan pada instansi pemerintah sesuai dengan Peraturan Perundang-Undangan yang berlaku dan yang di tetapkan oleh pemerintah yang berwenang. Adapun pengangkatan tenaga harus memnuhi persyaratan kerja, persyaratan kerja yang di maksud adalah berupa ljazah dan Transkrip Nilai. Perekrutan tenaga Perawat oleh pemerintah yaitu bertujuan untuk memberikan pelayanan kesehatan terhadap masyarakat.

\section{b. Syarat Perekrutan}

Pengangkatan tenaga Perawat untuk di pekerjakan pada instansi pemerintah di upayakan harus memiliki Surat Tanda Registrasi yang selanjutnya di singkat sebagai STR. Hal tersebut sebagaimana yang di atur dalam Pasal 18 ayat (1) Undang-Undang Keperawatan yang menerangkan bahwa : "Perawat yang menjalankan Praktik Keperawatan wajib memiliki STR". Hal tersebut di atur pula dalam Pasal 44 ayat (1) Undang-Undang Tenaga Kesehatan yang menerangkan bahwa : "Setiap Tenaga 
Kesehatan yang menjalankan praktik wajib memiliki STR". Adapu persyaratan untuk mendapatkan STR sebagaimana yang di atur dalam Pasal 18 ayat (3) UndangUndang Keperawatanyang menerangkan bahwa : "Persyaratan sebagaimana dimaksud meliputi: a. memiliki ijazah pendidikan tinggi Keperawatan; b. memiliki Sertifikat Kompetensi atau Sertifikat Profesi; c. memiliki surat keterangan sehat fisik dan mental; d. memiliki surat pernyataan telah mengucapkan sumpah/janji profesi; dan e. membuat pernyataan mematuhi dan melaksanakan ketentuan etika profesi". Selain itu juga di atur dalam Pasal 44 ayat (3) Undang-Undang Tenaga Kesehatan yang menerangkan bahwa : "Persyaratan sebagaimana dimaksud meliputi : a. memiliki ijazah pendidikan di bidang kesehatan. b. memiliki Sertifikat Kompetensi atau Sertifikat Profesi. c. memiliki surat keterangan sehat fisik dan mental. d. memiliki surat pernyataan telah mengucapkan sumpah/janji profesi. Dane. membuat pernyataan mematuhi dan melaksanakan ketentuan etika profesi".

Pengangkatan tenaga Perawat untuk di berpraktik pada instansi pemerintah harus memenuhi persyaratan sebagaimana yang di atur dalam Undang-Undang Keperawatan di atas. Pengaturan pengangkatan tenaga tidak terlepas dari Peraturan Peundang-Undangan yang berlaku sebagai acuan untuk merekrut tenaga. Tenaga Perawat yang bekerja pada instansi pemerintah harus memenuhi persyaratan sebagaimana yang di atur dalam Pasal tersebut di atas. Dengan adanya STR merupakan syarat kerja bagi setiap tenaga Perawat yang bekerja pada instansi pemerintah seperti di Rumah Sakit dan Puskesmas. Kebutuhan tenaga untuk di pekerjakan pada instansi pemerintah tidak terlepas dari perekrutan tenaga sebagai Sumber Daya Manusia yang selanjutnya di singkat sebagai SDM kesehatan.

\section{c. Kewenagan}

1 Dinas Kesehatan

Pemerintah dalam bidang kesehatan memiliki kewenagan melakukan perencanaan dan pengadaan tenaga sebagai SDM kesehatan sebagaimana yang di atur juga dalam pasal 21 ayat 1 undang-undang Nomor 36 Tahun 2009 tentang kesehatan yang menerangkan bahwa : "Pemerintah mengatur perencanaan, pengadaan, pendayagunaan, pembinaan, dan pengawasan mutu tenaga kesehatan dalam rangka penyelenggaraan pelayanan kesehatan".

Dinas Kesehatan yang merupakan bagian dari organisasi perangkat daerah dalam melaksanakan kegiatan penunjang memiliki kewenagan dalam Perencanaan dan pengadaan tenaga sebagai SDM kesehatan pada lingkup Puskesmas. Adapun kewenagan dinas kesehatan sebagaimana yang di atur dalam Lampiran I hurf B angka 2 tentang Sumberdaya Daya Manusia (SDM) Kesehatan Undang-Undang Nomor 23 Tahun 2014 Tentang Pemerintah Daerah yang menerangkan bahwa : "Pembagian urusan pemerintah daerah dalam bidang kesehatan adalah penerbitan izin praktik dan izin kerja tenaga kesehatan dan perencanaan dan pengembangan SDM kesehatan untuk UKM dan UKP Daerah kabupaten/kota".

Perencanaan dan pengembagan SDM Kesehatan merupakan urusan yang menjadi kewenagan Dinas Kesehatan sebagai perangkat daerah yang menyelenggarakan urusan pemerintah dalam bidang kesehatan hal tersebut sebagai mana yang di atur dalam Pasal 3 huruf $d$ angka 2) peraturan daerah Nomor 4 Tahun 2014 Tentang Pembentukan Dan Susunan Perangkat Daerah 
Kabupaten Bima yang menerangkan bahwa: "Perangkat daerah sebagaimana dimaksud dalah Dinas Kesehatan, menyelenggarakan urusan pemerintahan bidang Kesehatan, dengan Dinas Daerah Tipe A".

Dinas Kesehatan sebagai UPT kesehatan pada wilayah Kabupaten sebagai pemerintah Tipe A dalam bidang kesehatan merupakan pemerintah yang di beri kewenagan untuk mengawasi kerja Rumah Sakit dan Puskesmas karena Rumah Sakit dan Puskesmas merupakan fasilitas pelayanan kesehatan di bawah pengawasan Dinas Kesehatan.

Pengawasa yang dilakukan oleh Dinas Kesehatan terhadap Puskesmas yaitu untuk meningkatkan pelayanan kesehatan terhadap masyarakat sebagai penerima pelayanan yang dilakukan oleh tenaga kesehatan yang salah satunya adalah tenaga Perawat. Selain pengawasan terhadap kerja tenaga Perawat Dinas Kesehatan juga memiliki kewenagan dalam mengawasi kebutuhan tenaga oleh Puskesmas. Untuk itu Dinas Kesehatan dan Puskesmas memiliki kewenagan dalam perencanaan dan pengadaan tenaga sebagai SDM kesehatan untuk di pekerjakan pada wilayah Kerja Puskesmas.

2 Puskesmas

Puskesmas dalam rangka terwujudnya Kecamatan sehat mempunyai tugas dalam melaksanakan kebijakan untuk mencapai terwujudnya pembangunan sehat. Tugas Puskesmas dalam melaksanakan kebijakan di Puskesmas sebagaimana yang di atur dalam Pasal 4 Peraturan Menteri Kesehatan No 75 Tahun 2014 tentang Puskesmas yang menerangkan bahwa : "Puskesmas mempunyai tugas melaksanakan kebijakan kesehatan untuk mencapai tujuan pembangunan kesehatan di wilayah kerjanya dalam rangka mendukung terwujudnya kecamatan sehat".

Tugas sebagaimana yang di jelaskan dalam pasal di atas yaitu melaksanakan kebijakan dalam wilayah Puskesmas terkait dengan pelayanan kesehatan dalam mendukung terwujudnya kecamatan yang sehat. Kebijakan yang di maksud juga tidak terlepas dari kebutuhan tenaga dalam penyelenggaraan UKM tingkat pertama di wilayah kerja Puskesmas, hal tersebut sebagaimana yang di atur dalam Pasal 6 huruf a Peraturan Menteri Kesehatan Tentang Puskesmas yang menerangkan bahwa : "Dalam menyelenggarakan fungsi sebagaimana dimaksud Puskesmas berwenang untuk melaksanakan perencanaan berdasarkan analisis masalah kesehatan masyarakat dan analisis kebutuhan pelayanan yang diperlukan".

Puskesmas dalam menyelenggarakan fungsinya berwewenang merencanakan kebutuhan tenaga kesehatan untuk di pekerjakan pada Puskesmas demi meningkatkan pelayanan kesehatan. Kebutuhan tenaga oleh Puskesmas meliputi tenaga Kesehatan dan non kesehatan hal tersebut sebagaimana yang di atur dalam Pasal 16 ayat (1) Peraturan Menteri Kesehatan tentang Puskesmas yang menerangkan bahwa : "Sumber daya manusia Puskesmas terdiri atas Tenaga Kesehatan dan tenaga non kesehatan".

Perencanaan dan pengadaan tenaga sebagai SDM Kesehatan untuk di pekerjakan pada Puskesmas merupakan kewenagan Puskesmas karena yang mengetahui adanya kekurangan dan kebutuhan tenaga adalah Puskesmas 
sebagai tempat kerja tenaga kesehatan. Puskesmas merupakan tempat perkumpulan tenaga kesehatan dan tenaga non kesehatan untuk menjaankan program pemerintah dalam memberikan pelayanan kesehatan tehadap masyrakat di tingkat pertama.

Kebutuhan tenaga kesehatan oleh Puskesmas tidak terlepas dari peran serta Pemerintah daerah bidang kesehatan dalam merencanakan kebutuhan tenaga sehingga pemerintah dapat menetapkan mengangkat tenaga yang di butuhkan oleh Puskesmas. Sebelum merencanakan kebutuhan tenaga kesehatan dan non kesehatan untuk di pekerjakan pada Puskesmas, maka kebutuhan tenaga tersebut harus melihat luas wilayah dan ketersediaan fasilitas pelayanan kesehatan pada wilayah kerja Puskesmas itu sendiri hal tersebut sebagaimana yang di atur dalam Pasal 16 ayat (2) Peraturan Menteri Kesehatan yang menerangkan bahwa : "Jenis dan jumlah Tenaga Kesehatan dan tenaga non kesehatan sebagaimana dimaksud pada ayat (1) dihitung berdasarkan analisis beban kerja, dengan mempertimbangkan jumlah pelayanan yang diselenggarakan, jumlah penduduk dan persebarannya, karakteristik wilayah kerja, luas wilayah kerja, ketersediaan fasilitas pelayanan kesehatan tingkat pertama lainnya di wilayah kerja, dan pembagian waktu kerja”.

Kebutuhan tenaga untuk di pekerjakan pada Puskesmas sebagaimana yang di atur dalam pasal di atas perlu melihat dan mempertimbangkan jumlah penduduk, luas wilayah dan ketersedian fasilitas pelayanan kesehatan pada wilayah kerja Puskesmas, sehingga dengan demikian kebutuhan tenaga oleh Puskesmas dapat di hitung dan di lihat sejauh mana beban kerja yang akan di limpahkan ke tenaga yang di butuhkan oleh Puskesmas dalam memberikan pelayanan kesehatan terhadap masyarakat.

3 Pejabat Pembina Kepegawaian

Perekrutan tenaga untuk di pekerjakan pada instansi pemerintah merupakan kewenagan Pejabat Pembina Kepegawaian. Hal tersebut sebagaimana yang di atur dalam Pasal 1 angka 6 Peraturan Bupati Bima Tentang Pedoman Pengangkatan, Penempatan, Pemberhentian Dan Disiplin Tenaga Honorer Daerah Lingkup Pemerintah Kabupaten Bima yang menerangkan bahwa : "Pejabat yang Berwenang adalah Pejabat Pembina Kepegawaian yang mempunyai kewenangan mengangkat, memindahkan dan memberhentikan Tenaga Honorer Daerah". Hal tersebut sebagaimana pula yang di atur dalam Pasal 98 ayat (1) Undang-Undang Aparatur Sipil Negara yang menerangkan bahwa : "Pengangkatan calon PPPK ditetapkan dengan keputusan Pejabat Pembina Kepegawaian".

Sebagaimana yang di jelaskan dalam peraturan di atas bahawa Pejabat Pembina Kepegawaian mempunyai kewenagan dalam mengangkat tenaga untuk di pekerjakan pada instansi pemerintah. Tujuan pengangkatan tenaga untuk di pekerjakan pada instansi pemerintah yaitu untuk memberikan pelayana atau membantu pemerintah dalam menjalankan dan melancarkan program pemerintah. 
Kewenagan merupakan hak dalam melakukan sesuatu atau kekuasaan dalam memerintahkan orang lain dalam melakukan suatupekerjaan agar tercapainya tujuan yang harapkan. Dalam dunia kerja pemerintah di beri kewenagan dalam menjalankan program yang harus dan wajib di kerjakan demi tercapainya suatu tujuan bersama. Adapun tujuan pemerintah dalam bidang kesehatan adalah untuk meningkatkan pelayanan kesehatan kepada masyarakat. Dengan adanya tujuan tersebut maka pemerintah dan pemerintah daerah di beri kewenagan dalam menjalankan dan melaksanakan program tersebut. Agar tercapainya tujuan pemerintah tersebut maka tida terlepat dari kebutuhan tenaga untuk menjalankan dan melancarkan program dalam dunia kesehatan.

Bupati sebagai Pejabat Pembina Kepegawaian yang mempunyai program tentunya memiliki kewenagan dalam mengangkat dan menempatkan tenaga Perawat pada fasilitas pelayanan kesehatan sebagai instansi pemerintah. sebelum di lakukan pengangkatan tenaga oleh Bupati maka perlu adanya perencanaan kebutukan tenaga. Untuk itu pimpinan instansi seperti Kepala Puskesmas yang mengetahui adanya kekurangan tenaga pada Puskesmas di berikan kewenagan dalam melakukan perencanaan kebutuhan tenaga. Akan tetapi perencanaan kebutuhan tenaga oleh Kepala Puskesmas tersebut tidak terlepas dari pengetahuan Dinas Kesehatan. Karena Dinas Kesehatan memiliki kewenangan dalam kerja Puskesmas, baik itu dalam pencapaian pelayanan kesehatan terhadap masyarakat serta kebutukan tenaga oleh Puskesmas.

2. Pelakanaan perlindungan hukum bagi Perawat Non PNS di Puskesmas pada Kecamatan Langgudu, Kabupaten Bima setelah berlakunya Undang-Undang Nomor 38 Tahun 2014 tentang Keperawatan.

\section{a. Perencanaan}

Tabel 1.1 Profil Puskesmas Kecamatan Langgudu. ${ }^{7}$

\begin{tabular}{|c|l|c|c|}
\hline No & \multicolumn{1}{|c|}{ Item } & $\begin{array}{c}\text { Puskesmas } \\
\text { Langgudu Barat }\end{array}$ & $\begin{array}{c}\text { Puskesmas } \\
\text { Langgudu Timur }\end{array}$ \\
\hline 1 & Jumlah Cakupan Desa & 10 Desa & 5 Desa \\
\hline 2 & Jumlah Pustu & 7 Buah & 4 Buah \\
\hline 3 & Jumlah Polindes & 2 Buah & 1 Buah \\
\hline 4 & Jumlah Poskesdes & 2 Buah & - \\
\hline 5 & Sumber Daya Manusia & 95 Orang & 32 Orang \\
\hline 6 & $\begin{array}{l}\text { Jumlah Tenaga } \\
\text { Keperawatan }\end{array}$ & 24 Orang & 12 Orang \\
\hline \multirow{4}{*}{7} & $\begin{array}{l}\text { Status Kepegawaian } \\
\text { Tenaga Keperawatan }\end{array}$ & & \\
\cline { 2 - 4 } & ASN & 9 Orang & 2 Orang \\
\cline { 2 - 4 } & PTT & 1 Orang & 3 Orang \\
\cline { 2 - 4 } & Honor Daerah & 13 Orang & 1 Orang \\
\cline { 2 - 4 } & Sukarela & 6 Orang \\
\hline
\end{tabular}

Sumber : Hasil Surfei Dan Penelitian

\footnotetext{
${ }^{7}$ Data yang di dapat pada Puskesmas Langgudu Kabupaten Bima Pada Tanggal 25 Agustus 2017
} 
Pada tabel tersebut di atas menunjukan Kecamatan Langgudu di layani oleh dua Puskesmas yaitu Puskesmas Langgudu dan Puskesmas Langgudu Timur dan masingmasing Puskesmas memiliki memiliki wilayah kerja. Tenaga Perawat yang berpraktik pada Puskesmas Kecamatan Langgudu terdiri dari tiga status tenaga yaitu tenaga Perawat PNS, Honorer daerah/PTT dan Sukarela.

Tenaga Perawat yang ada pada Puskesmas di wilayah Kecamatan Langgudu di lihat dari jumlah tenaga Prawat dapat di katakan masih kurang sehingga pemerintah perlu merencanakan kebutuhan tenaga Perawat untuk di pekerjakan di Puskesmas pada Kecamatan Langgudu. Kurangnya tenaga Perawat di Puskesmas pada Kecamatan Langgudu di akibatkan pemahaman Puskesmas terkait dengan fungsinya dalam merencanakan kebutuhan tenaga untuk di pekerjakan pada Puskesmas masih kurang.

Permasalahan yang di hadapi oleh birokrasi pemerintah akibat kelembagaan birokrasi pemerintah yang besar dan tidak di dukung oleh sumberdaya aparatur yang profesional, dan penataan sumber daya aparatur yang tidak di sesuaikan dengan kebutuhan dan penataan kelembagaan birokrasi, memaksa pemerintah untuk melakukan perampingan lembaga dengan menerapkan sistim zero growth. Artinya pengadaan pegawai/rekrut di dasarkan untuk mengganti yang pensiun, sehingga pengadaan pegawai tidak harus di lakukan tiap tahunn. ${ }^{8}$ Dengan adanya pegawai yang pensiun maka perlu di lakukan perencanaan kebutuhan tenaga sebagai pengganti agar tidak terjadi kekosongan tenaga. Akan tetapi pada pelaksanaanyan tenaga Perawat yang ada di Kecamatan Langgudu masih kurang sehingga perlu di lakukan perencanaan kebutuhan tenaga Perawat oleh Pemerintah. Karena Pemerintah Daerah yang memiliki kewenangan dalam hal perencanaan dan pengadaan tenaga untuk di pekerjakan pada instansi pemerintah lingkup daerah dan di bantu oleh Badan Kepegawaian Daerah yang selanjutnya di sebut BKD.

Perencanaan kebutuhan tenaga oleh pemerintah daerah di atur dalam prodak hukum akan tetapi pada pelaksanaanya perencanaan kebutuhan tenaga Perawat oleh pemerintah daerah masih kurang sehingga menyebabkan Kepala Puskesma mengangkat tenaga untuk di pekerjakan pada Puskesmas. Kepala Puskesmas dalam mengangkat tenaga tidak merencanakan terlebih kebutuhan tenaga Dinas Kesehatan sehingga tenaga Perawat yang di angkat oleh Kepala Puskesmas tidak mendapatkan perlindungan dari pemerintah.Pada hal jika di lihat dari jumlah fasilitas pelayanan kesehatan dan jumlah tenaga Perawat pada Puskesmas Kecamatan Langgudu masih kurang sehingga Bupati dan Dinas Kesehatan serta Kepala Puskesmas sebagai OPD perlu merencanakan kebutuhan tenaga sebagai SDM Kesehatan.

\section{b. Pengangkatan}

Pengangkatan tenaga Perawat untuk di pekerjakan pada Puskesmas sebagai instansi pemerintah, hal tersebut tidak terlepas dari perekrutan tenaga oleh pemerintah yang berweweng. Karena tujuan dari pengangkatan tenaga yaitu untuk memberikan pelayanan dan meningkatkan pelayanan kesehatan kepada masyarakat.

Tenaga kesehatan khususnya tenaga Perawat yang bekerja di daerah kabupaten Bima di bagi menjadi dua golongan/status yaitu tenaga Perawat PNS dan Tenaga Perawat Non PNS (Perawat Honorer Daerah, Perawat PTT Daera dan Perawat Sukarela) hal

${ }^{8}$ Sri Hartini, Hj. Setiajeng Kadarsih, Tedi Sudrajat, 2010, Hukum Kepegawaian Indonesia, Jakarta : Sinar Grafika.. Hal. 119 
tersebut sebagaimana yang di jumpai pada penelitian. Tenaga Perawat sukarela yang bekerja di Puskesmas pada Kecamatan Langgudu secara keseluruhan di rekrut oleh Kepala Puskesmas. Munculnya hubungan tersebut akibat dari adanya suarat lamaran kerja yang di ajukan tenaga Perawat kepada Kepala Puskesmas. Kemudian dari Kepala Puskesmas mengeluarkan Surat Keputusan tentang pengangkatan tenaga sukarela untuk di pekerjakan pada Puskesmas yang di tanda tangani oleh Kepala Puskesmas. pengangkatan tersebut tidak di berikan gaji yang bersumber dari apapun yang ada di Puskesmas.

Adapun tenaga Perawat Non PNS yang yang bekerja di Puskesmas Pada Kecamatan Langgudu adalah tenaga Perawat Honorer Daerah, tenaga Perawat PTT Daerah, dan tenaga Perawat Sukarela.

1. Perawat Honorer Daerah

Tenaga Perawat honorer daerah yang bekerja pada Puskesmas Langgudu pada pelaksanaanya di angkat oleh Bupati yang bersifat tetap dan mendapatkan gaji dari pemerintah daerah yang bersumber dari APBD tahun 2006 sebesar Rp 200.000 perbulan.

2. Perawat PTT Daerah

Tenaga Perawat PTT Daerah merupakan tenaga yang di angkat oeleh Pemerintah daerah yang bersifat tidak tetap dengan masa kontrak paling lama satu tahun, akan tetapi dapat di perpanjang tiap tahunya. Sistim pemberian upah tenaga Perawat PTT Daerah tersebut pada pelaksanaanya di bebankan pada DPA Dinas Kesehatan Kabupaten Bima. Gaji tenaga Perawat PTT daerah Rp 600.000 perbulan. Adapun sistim penerimaan gaji tenaga Perawat PTT Daerah tiga bulan sekali sebesar Rp. 1.800.000.

3. Perawat Perawat Sukarela

Tenaga Perawat sukarela yang bekerja pada Puskesmas di angkat oleh Kepala Puskesmas dengan tujuan untuk memberikan pelayanan kesehatan padamasyarakat. Akan tetapi tenaga Perawat sukarela tersebut sistimpemberian upah tidak di bebankan pada sumber apapun yang ada padaPuskesmas.

Adapun perjanjian kerja terdiri dari tiga unsur yang menentukan adanya hubungan kerja adalah Adanya pekerjaan yang harus dilakukan, Adanya perintah (bekerja atas perintah atasan/pengusaha) dan adanya upah. ${ }^{9}$ Dalam perjanjian kerja harus memenuhi ketiga Unsur tersebut, apabila salah satunya tidak terpenuhi maka perjanjian tersebut tidak sah demi hukum. Untuk itu tenaga Perawat yang di angkat oleh Kepala Puskesmas jika di lihat dari isi SK yang tidak mencantumkan upah atau gaji bagi tenaga Perawat yang di angkat maka SK perjanjian tersebut batal demi hukum karena tidak memenuhi hak tenaga Perawat atas pekerjaanya yang di lakukan selama mengabdikan dirinya pada Puskesmas.

Pengangkatan tenaga Perawat yang di lakukan oleh Kepala Puskesmas yang ada di Kabupaten Bima pada pelaksanaannya bertentangan dengan Peraturan PerundangUndangan yang berlaku karena puskesmas tidak di berikan kewenaga

\footnotetext{
${ }^{9}$ Greta Satya Yudhana, 2015, Jurnal Pelaksanaan Perlindungan Hukum Bagi Pekerja Honorer Kebersihan Kota Di Pemda Yogyakarta, Hal, 11. Yang Di Akses Dari : http://e-journal.uajy.ac.id/8019/1/JURNAL.pdf, Pada Tanggal 15 pebruari 2018 Jam 19:17 WIB
} 
dalammengangkat tenaga sehingga berimplikasi pada perlindungan hukum bagi tenaga Perawat itu sendiri. Karenapengangkatan tenaga oleh Kepala Puskesmas tanpa di berikan gaji hal tersebut sebagaimana yang di lihat dari isi SK pada poin Kedua menyebutkan bahwa : "pembayaran penghasilan tidak di bebankan dari sumber apapun di Puskesmas Langgudu". Tenaga Perawat yang di angkat oleh Kepala Puskesmas hanya mendapatkan upah dari hasil Pelayanan yang di terima tiga bulan sekali.

\section{c. Perlindungan}

Keberadaan hukum tidak dapat dilepaskan dari pertimbangan-pertimbangan politik, ekonomi, sosial, dan budaya. Memang, faktor-faktor itu tidak dapat dinafikkan begitu saja, akan tetapi pertombangan-pertimbangan itu tidak boleh menyisihkan esensi hukum. Pertimbangan-pertimbangan itu merupakan sisi eksternal hukum yang mengandung mendukung keberdaan hukum, namun bukan merupakan suatu yang instrinsik dalam hukum. ${ }^{10}$

Hak dan kewajiban dalam hubungan hukum, hak merupakan segala sesuatu yang wajib di dapatkan sedangkan kewajiban merupakan segala sesuatu yang harus di kerjakan. Hubungan hukum antara pemerintah selaku pemberi kerja dengan tenaga Perawat karena adanya perjanjian kerja antara pemerintah dengan tenaga Perawat sehingga lahirlah suatu perikatan yang mengakibatkan adanya hak dan kewajiban. Adapun hak tersebut adalah hak untuk mendapatkan perlindungan hukum dari pemerintah sebagai pemberi kerja, sedangkan kewajiban adalah segala sesuatu yang harus di kerjakan sebagai tanggung jawab dalam hubungan kerja. Perlindungan hukum yang di maksud adalah Perlindungan atas hak, baik itu hak untuk mendapatkan upah atau gaji dan hak untuk mendapatkan cuti serta hak untuk mendapatkan kepastian hukum bagi tenaga Perawat.

Menurut Van Apeldoorn, kepastian hukum berarti perlindungan hukum. ${ }^{11}$ Jadi dapat di katakan bahwa adanya perlindungan hukum karena adanya kepastian hukum. Agar tenaga Perawat yang di angkat oleh Kepala Puskesmas mendapatkan perlindungan hukum maka pemerintah harus memberikan kepastian hukum bagi tenaga Perawat. Denagan adanya kepastian hukum bagi tenaga Perawat yang bekerja pada Puskesmas maka tenaga Perawat tersebut akan mendapatkan Perlindungan hukum.

Adapun bentuk dari suatu perlindungan dan kepastian hukum bagi tenaga Perawat adalah melakukan perjanjian kerja yang memuat hak-hak dan kewajiban sehingga dengan demikian di harapkan pemerintah tidak lagi memperlakukan tenaga Perawat sewenang-wenag tanpa memenuhi hak atas kewajiban atau memutuskan hubungan kerja sepihak tanpa melihat kebutuhan tenaga Perawat sebagaiman ketentuan Peraturan Perundang-Undangan yang berlaku.

Adanya hubungan kerja antara pemerintah dengan tenaga perawat tidak terlepas dari hak kewajiban.

1. Hak dan Kewajiban Pegawai Perawat

Adapun hak tenaga Perawat sebagai pegawai yang bekerja pada Puskesmas adalah untuk mendapatkan gaji dari pemerintah sedangkan kewajibannya adalah memberikan pelayanan kesehatan kepada masyarakat.

\footnotetext{
${ }^{10}$ Peter Muhamad Marjuki , 2008, Pengantar Ilmu Hukum, Jakarta : Kencana. Hal. 87

${ }^{11}$ Peter Mahmud Marzuki, 2005, Penelitian Hukum, Jakarta : Fajar Inter Pratama Offset, Hal. 60
} 
2. Hak dan Kewajiban Pemerintah

Adapun hak pemerintah adalah untuk mendapatkan atau memperoleh hasil dari kerja tenaga Perawat sedangkan kewajibannya adalah untuk memberikan upah kepada tenaga Perawat sebagai pegawai yang bekerja pada instansi pemerintah tersebut.

Adapun pengkategorian gaji tenaga Perawat sebagai tenaga yang bekerja pada instansi pemerintah adalah gaji pokok, tunjangan tetap dan tunjangan tidak tetap.

1. Gaji Pokok adalah upah dasar yang dibayarkan oleh pemerintah kepada pegawai menurut pangkat atau golongan dengan jenis pekerjaan yang ditetapkan sesuai dengan kesepakatan kerja.

2. Tunjangan Tetap adalah pembayaran yang di berikan kepada pegawai secara teratur yang berkaitan dengan suatu pekerjaan yang telah diberikan secara tetap. Tunjangan tetap tersebut dibayarkan dalam satuan waktu secara bersamaan dengan pembayaran gaji pokok.

3. Tunjangan Tidak Tetap adalah pembayaran yang di berikan baik itu secara langsung maupun tidak langsung yang berkaitan dengan suatu pekerjaan. Tunjangan tidak tetap bagi pegawai dan keluarganya dapat dibayarkan dalam waktu yang tidak sama dengan pembayaran gaji pokok. Adapun tunjangan tidak tetap seperti uang transport dan tunjangan makan yang di hitung berdasarkan pada kehadiran.

3. Hambatan perlindungan hukum bagi Perawat Non PNS di Puskesmas pada Kecamatan Langgudu, Kabupaten Bima setelah berlakunya Undang-Undang Nomor 38 Tahun 2014 tentang Keperawatan.

Pemerintah dalam menjalankan fungsinya, tentunya mengalami hambatan, baik itu hambatan yang bersumber dari dalam diri maupun yang berasal dari Peraturan Perundang-Undangan yang di jadikan dasar hukum dalam memberikan perlindungan bagi tenaga sebagai pegawai yang bekerja pada puskesmas sebagai instansi pemerintah.

\section{a. Hambatan SDM}

Dengan adanya tenaga Perawat Non PSN yang bekerja pada pada Puskesmas yang di angkat oleh Kepala Puskesmas merupakan hambatan bagi pemerintah daerah dalam memberikan perlindungan hukum bagi tenaga Perawat karena kepala Puskesmas tidak di beri kewenagan dalam mengangkat tenaga Perawat untuk dipekejakan pada Puskesmas sebagai instansi pemerintah.

\section{Kurangnya pengetahuan}

a. Kurangnya pengetahuan Kepala Puskesmas tentang menejemen perekrutan tenaga untuk di pekerjakan pada Puskesmas.

b. Keterbatasan pengetahuan Kepala Puskesmas tentang Peraturan Perundang-Undangan yang di jadikan dasar hukum dalam memberikan perlindungan dan kepastian hukum bagi tenaga tenaga Perawat.

c. Kurangnya pengetahuan Kepala Puskesmas terkait dengan kewenagannya sebagai pimpinan Puskesmas 
Keterbatasan pengetahuan Kepala Puskesmas terkait dengan sistim perekrutan tenaga mengakibatkan tenaga Perawat tidak mendapatkan haknya sebagai pegawai yang bekerja pada instansi pemerintah. Keberadaan tenaga Perawat Sukarela yang bekerja pada Puskesma sebagai instansi pemerintah di karenakan adanya ketebatasan pengetahuan Kepala Puskesmas terkait dengan menejemen perekrutan tenaga untuk di pekerjakan pada Puskesmas. Selain itu juga Kepala Puskesmas mengalami keterbatasan pengetahuan tentang Peraturan Perundang-Undangan terkait dengan kewenagan dalam hal menejemen perekrutan tenaga serta perlindungan bagi tenaga Perawat yang bekerja pada Puskesmas. Dengan adanya keterbatasan pengetahuan tersebut sehingga perimpikali pada pada perlindungan hukum bagi tenaga Perawat itu sediri.

Kemampuan Kepala Puskesmas terkait dengan kewenangannya dalam menejemen perekrutan tenaga masih kurang sehingga Kepala Puskesmas berani menerima dan mengangkat tenaga dengan istilah tenaga sukarela, tanpa mengetahui batas-batas kewenaganya. Selain itu juga Kepala Puskesmas kurang memahami aturan-aturan sebagai prodak hukum yang di jadikan acuan dalam perekrutan tenaga Perawat sehingga menyebabkan peningkatan jumlah tenaga Sukarela pada wilayah Kabupaten Bima.

\section{Kurangnya Informasi}

Kurangnya informasi kebutuhan tenaga Perawat dari Kepala Puskesmas dan Dinas Kesehatan merupakan suatu hambatan bagi pemerintah daerah dalam merencanakan anggaran sebagai biaya untuk memberikan upah kepada pegawai. Selain itu juga tidak transparansinya perekrutan tenaga oleh pemerintah merupakan hambatan bagi tenaga Perawat untuk mendapatkan pekerjaanya dengan perjanjian kerja.

Dengan adanya kurang informasi dan tidak transparansinya perekrutan tenaga oleh pemerintah menyebabkan tenaga Perawat melamar kerja ke Puskesmas. Adanya lamaran kerja tersebut membuat kepala Puskesmas menerima tenaga tanpa adanya perencanaan kebutuhan tenaga sehingga tenaga Perawat yang di rekrut tidak mendapatkan perlindungan dan kepastian hukum sebagai pegawai yang bekerja pada instansi pemerintah.

\section{Kurangnya anggaran}

Kuranyan persediaan anggaran untuk rencana kebutuhan tenaga di khawatirkan akan berdampak pada kegiatan yang akan di lakukan. Dengan tidak adanya anggaran dalam merencanakan kebutuhan tenaga sebagai SDM dalam kesehatan merupakan suatu masalah yang perlu di benahi oleh pemerintah. Karena tahap dalam suatu proses perencanaan kebutuhan tenaga kesehatan untuk di pekerjakan pada Puskesmas tidak dapat di lakukan dengan sempurna.

Perencanaan kebutuhan tenaga sebagai SDM kesehatan sebagaimana yang di jelaskan di atas tidak terlepas dari anggaran untuk melancarkan proses pelaksanaan. Sebelum merencanakan kebutuhan tenaga maka pemerintah harus mendapatkan informasi dan data yang akurat, selain itu pemerintah harus memiliki pemikiran yang luas sehingga dalam pelaksanaanya dapat menjelaskan tahap-tahap kegiatan dan harapan kedepan serta tujuan yang 
akan di capai. Implementasi kebijakan dalam suatu perencanaan kebutuhan tenaga kesehatan sangat di pengaruhi oleh data lain seperti ketersediaan dalam menjalankan tugas serta kecukupan tenaga yang ada pada Puskesmas, selaian itu juga adanya informasi tentang kebutuhan tenaga yang di sebarkan melalui media agar calon tenaga mendapatkan informasi.

\section{b. Hambatan Normatif}

Tidak ada aturan dari pemerintah daerah terkait dengan tenaga Keperawatan sebagai kelanjutan atau turunan dari Undang-Undang Keperawatan selain itu juga tidak adanya Peraturan pemerintah Daerah tentang mempekerjakan tenaga Sukarela pada instansi pemerintah. sehingga dengan tidak adanya peraturan tentang tenaga sukarela tersebut merupakan suatu hambatan bagi pemerintah daerah dalam memberikan perlindungan hukum bagi tenaga sukarela. Karena yang mengangkat tenaga sukarela adalah Kepala Puskesmas. Dalam Peraturan perundang-Undangan yang berhak dan yang mempunyai kewenagan dalam mengangkat tenaga untuk di pekerjakan pada Puskesmas sebagai instansi pemerintah adalah Bupati sebagai Pejabat Pembina Kepegawaian.

\section{KESIMPULAN}

1. Pengaturan perlindungan hukum bagi Perawat Non PNS di Puskesmas pada Kecamatan Langgudu, Kabupaten Bima setelah berlakunya Undang-Undang Nomor 38 Tahun 2014 tentang Keperawatan.

Penagaturan perlindungan hukum bagi pegawai di atur dalam Undang-Undang Nomor 5 Tahun 2014 Tentang ASN dan Peraturan Bupati Bima Nomor 15A Tahun 2014 Tentang Pedoman Pengangkatan, Penempatan, Pemberhentian, dan Disiplin Tenaga Honorer Daerah Lingkup Pemerintahan Kabupaten Bima. dengan adanya peraturan PerundangUndangan tersebut maka dapat memberikan perlindungan bagi setiap tenaga Perawat sebagai pegawai yang bekerja pada Puskesmas sebagai instansi pemerintah. Akan tetapi peraturan Perundang-Undangan tersebut hanya berlaku bagi tenaga atau pegawai ASN. Selain itu juga perlindungan bagi tenaga Perawata di atur dalam Undang-Undan Keperawatan dan Undang-Undang Tenaga Kesehatan karena tujuan di bentuknya Undang-Undang tersebut berasaskan Perlindungan.

Dalam Undang-Undang Nomor 5 Tahun 2014 Tentang ASN mengatur tentang kewenagan pejabat pembina kepegawaian dalam mengangkat tenaga untuk di pekerjakan pada instansi pemerintah. Sebagai kelanjutannya di daerah Kabupaten Bima di atur dalam Peraturan Bupati Bima Nomor 15A Tahun 2014 Tentang Pedoman Pengangkatan, Penempatan, Pemberhentian, dan Disiplin Tenaga Honorer Daerah Lingkup Pemerintahan Kabupaten Bima. Pejabat Pembina Kepegawaian yang di maksud adalah Bupati.

Pengangkatan tenaga untuk di pekerjakan pada puskesmas merupakan kewenangan Bupati sebagai pejabat pembina Kepegawaian sedangkan tugas dan kewenagan Kepala Puskesmas hanya melakukan perencanaan kebutuhan tenaga kesehatan untuk di pekerjakan pada Puskesmas. Perencanaan kebutuhan tenaga untuk di pekerjakan pada Puskesmas dengan tujuan untuk memberikan pelayanan kesehatan kepada masyarakat sebagaimana yang menjadi tujuan utuma pemerintah dalam bidangk kesehatan. 
2. Pelaksanaan perlindungan hukum bagi Perawat Non PNS di Puskesmas pada Kecamatan Langgudu, Kabupaten Bima setelah berlakunya Undang-Undang Nomor 38 Tahun 2014 tentang Keperawatan

Perlindungan hukum bagi tenaga Perawat sebagai pegawai yang bekerja pada Puskesmas mengacu pada Undang-Undang ASN. Dalam Undang-Undang tersebut mengatur tentang kewenagan pemerintah dalam mengangkat tenaga untuk di pekerjakan pada instansi pemerintah.

Penagakatan dan penempatan tenaga Perawat untuk di pekerjakan pada instansi pemerintah pada pelaksanaan ya di lakukan oleh Bupati dan Kepala Puskesmas. Penagangkatan dan penempatan tenaga Perawat oleh Bupati sudah sesuai dengan Undang-Undang ASN akan tetapi pengangkatan dan penempatan tenaga Perawat oleh Kepala Puskesmas tidak sesuai dan bertentangan dengan Undang-Undang ASN dan Peraturan Bupati Bima. Karena pengangkatan dan penempatan tenaga perawat oleh kepala Puskesmas tanpa mendapatkan gaji dari pemerintah, akan tetapi hanya mendapatkan upah dari hasil klaim.

Dengan adanya pengangkatan tenaga Perawat oleh Kepala Puskesmas tersebut menyebabkan tenaga Perawat tidak mendapatkan perlindungan hukum, baik itu perlindungan hukum terhadap hak atas kewajiban maupun kepastian hukumnya sebagai pegawai yang bekerja pada instansi pemerintah.

3. Hambatan perlindungan hukum bagi Perawat Non PNS di Puskesmas pada Kecamatan Langgudu, Kabupaten Bima setelah berlakunya Undang-Undang Nomor 38 Tahun 2014 tentang Keperawatan

Denagan adanya tenaga Perawat yang di pekerjakan oleh Kepala Puskesmas dalam memberikan pelayanan kesehatan kepada masyarakat di wilayah kerja Puskesmas pada Kecamatan Langgudu Kabupaten Bima merupakan hambatan bagi pemerintah dalam memberikan perlindungan hukum terhadap tenaga Perawat Sukarela.

Adanya penagangkatan tenaga Perawat oleh Kepala Puskesmas tersebut karena kurangnya pengetahuan Kepala Puskesmas terkait dengan menejemen perekrutan tenaga selain itu juga Puskesmas kurang paham tentang dasar Peraturan PerundangUndangang yang di jadikan dasar hukum dalam memberikan perlindungan terhadap tenaga yang di pekerjakan pada Puskesmas sebagai instansi pemerintah.

Dengan tidak adanya peraturan Perundang-Undangan tentang tenaga sukarela merupakan suatu hambatan bagi pemerintah dalam memberikan perlindunga karena tidak ada dasar hukum yang di jadikan acuan dalam memberikan suatu perlindungan. Adapun perlindungan yang di maksud adalah perlindungan hak atas kewajiban.

Pengangkatan tenaga Perawat dengan istilah tenaga Sukarela oleh Kepala Puskesmas sudah menyalahgunakan kewenaganya dan bertentangan dengan Undang-Undang ASN dan Undang-Undang Keperawatan itu sendiri. Karena tujuan di bentuknya UndangUndang Keperawatan yaitu berasaskan perlindungan. 


\section{Saran}

\section{Pemerintah}

Untuk menghindari penyalahgunaan kewenangan dalam mengangkat atau merekrut

tenaga untuk di pekerjakan pada instansi pemerintah di wilayah Kabupaten Bima, maka Bupati harus tegas dalam mengambil suatu keputusan. Dengan demikian dapat mengurangi peningkatan tenaga Perawat Sukarela pada wilayah kerja Kabupaten Bima.

Pemerintah dan pemerintah daerah dalam memenuhi hak pegawai yang bekerja pada instansi pemerintah yang dalam hal ini Puskesmas perlu melakukan penataan ulang terkait dengan penerimaan atau perekrutan pegawai dengan demikian akan mengurangi angka tenaga perawat sukarela yang bekerja pada puskesmas sebagai instansi pemerintah. Selain itu juga pemerintah dan pemerintah daerah harus memberikan informasi yang jelas terkait dengan perekrutan tenaga. Informasi yang di maksud harus bersifat publik agar setiap pelamar mendapatkan informasi bahwa pemerintah daerah membutuhkan tenaga untuk di pekerjakan pada instansi pemerintah.

Dengan adanya tenaga sukarela yang bekerja pada Puskesmas sebagai instansi pemerintah maka pemerintah dan pemerintah daerah harus mengangkat tenaga perawat sukarela tersebut secara bertahap sebagai pegawai pemerintah dengan ikatan kerja dalam waktu tertentu sesuai dengan masa mengabdi pada Puskesmas agar tenaga Perawat sukarela tersebut mendapatkan haknya sebagai pegawai dan mendapatkan kepastian hukum sebagai pegawai yang bekerja pada Puskesmas dalam menjalankan program pemerintah untuk meningkatkan pelayanan kesehatan kepada masyarakat.

\section{Dinas Kesehatan}

Dinas Kesehatan sebagai pemerintah dalam dunia kesehatan perlu melakukan pengawasan terhadap kerja Puskesmas baik itu dalam hal pelayanan maupun dalam kebutuhan tenaga oleh Puskesmas agar setiap tenaga yang bekerja pada Puskesmas mendapatkan perlindungan dan kepastian hukum dari pemerintah sebagai pegawai yang bekerja pada Puskesmas sebagai instansi pemerintah.

Pembinan dan pengawasan yang dilakukan oleh Dinas Kesehatan terhadap tenaga kesehatan yang bekerja pada Puskesmas sebagai pemerintah dalam dunia kesehatan sangat perlu untuk meningkatkan pelayanan kesehatan terhadap masyarakat pada wilayah Kecamatan sebagai wilayah kerja Puskesmas. Dengan adanya tenaga Perawat sukarela yang bekerja pada Puskesmas Langgudu maka Dinas Kesehatan harus mendata ulang jumlah tenaga tersebut baik itu tenaga Perawat ASN maupun tenaga Perawat sukarela agar kedepan dapat menganalisa seberapa banyak kebutuhan tenaga untuk di pekerjakan pada Puskesmas Langgudu. Dinas Kesehatan sebelum menetapkan kebutuhan tenaga perlu mengajukan ke Pejabat Pembina Kepegawaian untuk mengangkat tenaga yang sudah bekerja pada Puskesmas secara bertahap sesuai dengan masa mengabdi sehingga dengan demikian tenaga Perawat tersebut mendapatkan perlindungan serta kepastian hukum sebagai pegawai yang bekerja pada instansi pemerintah.

\section{Puskesmas}

Kepala Puskesmas dalam merekrut tenaga harus merencanakan terlebih dahulu terkait dengan kebutuhan tenaga untuk di pekerjakan pada Puskesmas. perencanaan tenaga oleh Puskesmas harus sepengetahuan Dinas Keshatan sebagai pemerintah dalam dunia 
kesehatan, dengan demikian setiap tenaga yang di butuhkan oleh Kepala Puskesmas untuk di pekerjakan pada Puskesmas akan mendapatkan perlindungan dan kepastian hukum sebagai Pegawai yang bekerja pada instansi pemerintah.

Kepala Puskesmas yang merekrut tenaga harus berupaya untuk memberikan poerlindungan hukum hak atas kewajiban bagi tenaga Perawat yang bekerja pada pada Puskesmas karena tenaga perawat yang di rekrut oleh kepala Puskesmas untuk membantu Puskesmas dalam meningkatkatkan pelayanan kesehatan terhadap masyarakat sebagaimana yang menjadi tujuan utama Puskesmas dalam menjalankan program pemerintah. Agar tercapainya tata kerja yang jelas dalam hal pengangkatan tenaga Perawat pada Puskesmas maka yang perlu di perhatikan adalah mematuhi Peraturan Perundang-Undangan yang berlaku.

\section{PPNI}

Sebagai organisasi perkumpulan Perawat maka PPNI harus berupaya untuk memperjuangkan hak setiap tenaga Perawat yang bekerja pada instansi pemeritah lebihlebih tenaga Perawat yang bekerja pada Puskesmas yang di rekrut oleh Kepala Puskesmas karena tenaga Perawat yang di rekrut oleh kepala Puskesmas tidak mendapatkan gaji dari pemerintah. Dengan adanya tenaga Perawat sukarela yang bekerja pada Puskesmas maka PPPNI sebagai organisasi persatuan Perawat harus berupaya memberikan perlindungan hukum bagi setiap tenaga Perawat selama menjalankan tugas sesuai dengan Standar Operasional Prosedur selain itu juga PPNI harus berupaya memperjuangkan hak tenaga Perawat untuk mendapatkan upah atau gaji dari pemerintah.

\section{Perawat}

Tenaga Perawat yang bekerja pada Puskesmas sebagai instansi pemerintah harus bekerja sesuai dengan SOP. Selain itu juga tenaga Perawat yang di rekrut oleh Kepala Puskesmas harus mendapatkan haknya sebagai pegawai bekerja pada Puskesmas sebagai instansi pemerintah. Tenaga Perawat yang direkrut oleh Kepala Puskesmas harus menuntut haknya sebagai pegawai yang bekerja pada instansi pemerintah karena setip tindakan tenaga Perawat dalam meberikan pelayanan kepada masyarakat merupakan tindakan dalam meningkatkan pelayanan kesehatan sebagaimana yang menjadi tujuan dari program pemerintah dalam bidang kesehatan.

\section{DAFTAR PUSTAKA}

Burhan Ashshofa, 2013, Metode Penelitian Hukum, Jakarta : Rineka Cipta

Greta Satya Yudhana, 2015, Jurnal Pelaksanaan Perlindungan Hukum Bagi Pekerja Honorer Kebersihan Kota Di Pemda Yogyakarta, Hal, 6. Yang Di Akses Dari : http://ejournal.uajy.ac.id/8019/1/JURNAL.pdf, Pada Tanggal 15 pebruari 2018 Jam 19:17 WIB

Kebersihan Kota Di Pemda Yogyakarta, Hal, 11. Yang Di Akses Dari : http://ejournal.uajy.ac.id/8019/1/JURNAL.pdf, Pada Tanggal 15 pebruari 2018 Jam 19:17 WIB

Ridwan, 2009, HukumAdministrasi Di Daerah, Yogyakarta : FH UII Pers

Peter Muhamad Marjuki , 2008, Pengantar Ilmu Hukum, Jakarta : Kencana

Peter Mahmud Marzuki, 2005, Penelitian Hukum, Jakarta : Fajar Inter Pratama Offset 
Sugiono : 2015, Metode Penelitian akuantitatif, kualitatif, R\&D. Bandung : Alfabeta

Sri Hartini, Hj. Setiajeng Kadarsih, Tedi Sudrajat, 2010, Hukum Kepegawaian Indonesia, Jakarta : Sinar Grafika.

Wahab,Lalu Husni,Zaenal Asyhadie, 2010 Dasar-Dasar Hukum Perburuhan Jakarta : Rajawali Pers

Undang-Undang Nomor 5 Tahun 2014 Tentang Aparatur Sipil Negara

Undang-Undang Nomor 38 Tahun 2014 Tentang Keperawatan

Undang-Undang Nomor 36 Tahun 2014 Tentang Tenaga Kesehatan

Peraturan Bupati Bima Nomor 15A Tahun 2014 Tentang Pedoman Pengangkatan, Penempatan, Pemberhentian, dan Disiplin Tenaga Honorer Daerah Lingkup Pemerintah Kabupaten Bima. 